Current Research in Psychology 1 (1): 67-70, 2010

ISSN 1949-0178

(C) 2010 Science Publications

\title{
Ageism in British Columbia: A Brief Report
}

\author{
${ }^{1}$ Larry Anderson and ${ }^{2}$ Yongjie Yon M.A. \\ ${ }^{1}$ Department of Psychology, Kwantlen Polytechnic University, \\ 12666-72nd Ave Surrey, BC Canada \\ ${ }^{2} 2000-515$ West Hastings Street, Vancouver, Canada
}

\begin{abstract}
This short report, using Palmore (2001) Ageism Survey, presents data demonstrating the prevalence of Ageism in British Columbia, Canada. Correlation patterns relating to humour, employment, victimization and personal rejection are discussed. Particular emphasis is placed on connecting ageism and relational self-esteem. Sources of respondents include: The Senior Connector, a newspaper distributed throughout British Columbia; the Council of Senior Citizen Organizations (COSCO), several Senior's Recreation centres throughout British Columbia and residents from a large seniors trailer park located in Aldergrove B.C. This study is a step toward understanding the nature of ageist experiences and development of approaches to reducing it. Another step is explicit strengthening of intergenerational relationships through community programming.
\end{abstract}

Key words: Ageism survey, patterns, prevalence, self-esteem

\section{INTRODUCTION}

Why this research is needed: As our population ages, ageism remains a threat to successful aging (Angus and Reeve, 2006).

The context of this work: Although much research on ageism has been generated in the United States there is considerably less activity in Canada. Ageism, perhaps less visible in Canada, has been described as a "quiet epidemic" (Stones and Stones, 1997). In light of population aging it is important to understand people's attitudes toward their elders and develop programs to improve intergenerational relations.

A growing problem: Research by Palmore (2004) found that older Canadians reported experiencing more ageist incidents than older Americans. Are Canadians really more ageist than Americans? This study, using Palmore (2001) Ageism Survey, attempts to examine the prevalence of ageism in British Columbia and discuss it's impact on seniors.

Robert Butler first coined the term ageism and defined it as "another form of bigotry" and "a process of systematic stereotyping and discrimination against people because they are old" (Butler, 1969). Ageism is different from the other types of "ism" such as sexism and racism. Unlike those forms of bias, ageism may affect anyone who lives long enough to become a target of discrimination. While there are both positive and negative aspects of ageism, in general, it has negative consequences for seniors (Palmore, 2005).

Although less visible, ageism does exist in Canadian society (Palmore, 2004). Until recently, there has been a lack of research in Canada to document the extent of prejudice towards older persons. Such documentation from the province of British Columbia (BC) can greatly benefit our understanding of ageism and lay the groundwork for change in attitudes and expectations of the aging process, creating a more age inclusive society.

\section{MATERIALS AND METHODS}

Recruitment and characteristics of participants: We recruited 815 seniors throughout the province of British Columbia from a wide base, ranging from members of; the Council of Senior Citizen Organizations (COSCO), several recreation centres, a Province wide senior's newspaper (The Seniors Connector) and a large senior's trailer park located in Aldergrove, B.C. All respondents were 55 or more years old.

Instrument: The Ageism Survey (Palmore, 2001) was used to assess the prevalence of ageism. The 20-item instrument has good internal reliability $($ alpha $=0.79)$ and provides incidents of ageism developed through ageism literature, discussions within academia and

Corresponding Author: Larry Anderson, Department of Psychology, Kwantlen Polytechnic University, 12666-72nd Ave Surrey, BC Canada 
Current Research in Psychology 1 (1): 67-70, 2010

Table 1: Prevalence of ageism in British Columbia

\begin{tabular}{|c|c|c|c|c|}
\hline \multirow[b]{2}{*}{ Event } & \multicolumn{2}{|c|}{ Never } & \multicolumn{2}{|c|}{ At least once } \\
\hline & $\mathrm{f}$ & Percentage & $\mathrm{f}$ & Percentage \\
\hline I was told a joke that makes fun of old people & 220 & 27.0 & 595 & 73.0 \\
\hline I was given a birthday card that makes fun of old people. & 376 & 46.0 & 438 & 53.0 \\
\hline I was ignored and not taken seriously because of my age & 583 & 71.5 & 232 & 28.0 \\
\hline I was called an insulting name related to my age & 685 & 84.0 & 130 & 16.0 \\
\hline I was patronized and "talked down to" because of my age & 544 & 67.7 & 271 & 33.3 \\
\hline I was refused rental housing because of my age. & 802 & 98.4 & 13 & 1.6 \\
\hline I had difficulty getting a loan because of my age & 772 & 94.7 & 43 & 5.3 \\
\hline I was denied a position of leadership because of my age & 768 & 94.3 & 46 & 5.7 \\
\hline I was rejected as unattractive because of my age & 755 & 92.6 & 60 & 7.4 \\
\hline I was treated with less dignity and respect because of my age & 632 & 77.6 & 182 & 22.4 \\
\hline A waiter or waitress ignored me because of my age & 688 & 84.4 & 125 & 15.4 \\
\hline A doctor or nurse assumed my ailments were caused by my age & 487 & 59.8 & 328 & 40.2 \\
\hline I was denied medical treatment because of my age & 775 & 95.2 & 39 & 4.8 \\
\hline I was denied employment because of my age & 731 & 89.7 & 84 & 10.3 \\
\hline I was denied a promotion because of my age & 761 & 93.5 & 53 & 6.5 \\
\hline Someone assumed I could not hear because of my age & 617 & 75.7 & 197 & 24.2 \\
\hline Someone assumed I could not understand because of my age & 630 & 77.3 & 184 & 22.6 \\
\hline Someone told me "You're too old for that." & 540 & 66.3 & 275 & 33.7 \\
\hline My house was vandalized because of my age & 787 & 96.6 & 28 & 3.4 \\
\hline I was victimized by a criminal because of my age & 780 & 95.0 & 34 & 4.2 \\
\hline
\end{tabular}

Note: Respondents $=815$

Table 2: Inter-item correlation of ageist survey

\begin{tabular}{|c|c|c|c|c|c|c|c|c|c|c|c|}
\hline & 1 & 2 & 3 & 5 & 10 & 14 & 15 & 16 & 17 & 19 & 20 \\
\hline 1. I was told a joke that makes fun at old people & & -- & & & & & & & & & \\
\hline 2. I was given a birthday card that pokes fun at old people & $0.56 * *$ & -- & & & & & & & & & \\
\hline 3. I was ignored or not taken seriously because of my age & 0.21 & 0.10 & -- & & & & & & & & \\
\hline 5. I was patronized or "talked down to" because of my age & 0.22 & 0.12 & $0.50 * *$ & -- & & & & & & & \\
\hline 10. I was treated with less dignity and respect & 0.15 & 0.06 & $0.52 * *$ & $0.50 * *$ & -- & & & & & & \\
\hline 14. I was denied employment because of my age & 0.06 & 0.05 & 0.13 & 0.05 & 0.13 & -- & & & & & \\
\hline 15. I was denied a promotion because of my age & 0.02 & 0.05 & 0.10 & 0.05 & 0.24 & $0.52 * *$ & -- & & & & \\
\hline 16. Someone assumed I could not hear because of my age & 0.15 & 0.08 & 0.25 & 0.29 & 0.31 & 0.08 & 0.05 & -- & & & \\
\hline 17. Someone assumed I could not understand & 0.10 & 0.02 & 0.40 & 0.45 & $0.41 * *$ & 0.11 & 0.18 & $0.54 * *$ & -- & & \\
\hline 19. My house was vandalized because of my age & 0.02 & 0.03 & 0.10 & 0.12 & 0.20 & 0.02 & 0.09 & 0.14 & 0.19 & -- & \\
\hline 20. I was victimized by a criminal because of my age & 0.03 & 0.00 & 0.20 & 0.17 & 0.23 & 0.00 & 0.03 & 0.12 & 0.19 & $0.53 * *$ & -- \\
\hline
\end{tabular}

Internal consistency alpha 0.852

groups of older persons. The survey covers only negative forms of ageism and includes examples of stereotypes, attitudes, personal and institutional discrimination. "The respondents were invited to Put a number in the blank that shows how often you have experienced that event: Never $=0$; Once $=1$; More than once $=2 "$ (Palmore, 2001).

Method: Respondents answered the surveys and returned them to the principle researcher directly or sent them in pre-addressed/stamped envelopes to the principle researcher's University address.

Statistical analysis: Internal reliability was tested using Cronbach's Coefficient Alpha. A factor analysis of principle components was used to test for commonality. Inter-item correlations were conducted. The analyses were tested at alpha levels of $0.05(*)$ and $0.01(* *)$.

\section{RESULTS}

Table 1 Summary of the results.

Table 2 Inter-item correlations between measures of ageism.

Humour: Seventy-three percent of the respondents indicated that they were told ageist jokes (item \#1). This item was the most frequently reported and, considering comments written by respondents, telling ageist jokes is the most contested form of ageism. Fiftythree percent reported being "sent an ageist birthday card"(item \#2). This was strongly correlated, with Item $1(\mathrm{r}=0.50, \mathrm{p}<0.001)$.

Health: Having a "doctor or nurse assume that an ailment was caused by age" was the next most reported prevalence $(40.2 \%)$ but was not significantly connected with any of the other items. 
Personal rejection: Item \#10 "treated with less dignity and respect was significantly correlated with four other items. The strongest was "being ignored and not taken seriously" ( $\mathrm{r}=0.52, \mathrm{p}<0.001)$, followed by "patronized and talked down to" $(\mathrm{r}=0.50 \mathrm{p}<0.001)$, "ignored by a waiter $(r=0.44 . p<0.001)$ and "assumed could not understand $(r=0.41, p<0.001)$.

Employment: There are three items connected with employment. They are "denied employment" correlated with "denied promotion $(\mathrm{r}=0.52, \mathrm{p}<0.01)$ which, in turn, is connected with "denied leadership" ( $\mathrm{r}=0.47$, $\mathrm{p}<0.001)$

Victimization: The two items were reported with the least frequency were "house vandalized" and "victim of crime" $(r=0.47 \mathrm{p}<0.001)$.

\section{DISCUSSION}

Humour: We found, like Palmore (2001), that there was some ambiguity in interpreting these results. Cynthia Rich, one of the founders of The Old Women's Project, in her interview with Lipscomb (2006) comments "We can do a scholarly analysis of birthday cards-the cards that inform me as an old woman just how disgusting and hideous I am. Then I'm chastised that I don't have a sense of humour when I object, the same comments we used to hear about sexist and racist jokes".

On the other hand humour is often exchanged between friends. "Friends spend a good deal of time in playful bandage in which no one gets hurt; indeed, an evening spent laughing with friends is one of life's greatest pleasures" (Pinker, 1999). Joking may be an outlet for older persons who have internalized the ageist cultural values about themselves and are releasing anxiety in a relatively safe environment. Ellis and Morrison (2005) suggest that joking about age among peers may be acceptable but is inappropriate when directed toward someone older than one's self.

Lang and Carstensen (1994) have highlighted the importance of close emotional relationships in old age and therefore, while older persons have smaller support networks, they are more selective in who they choose as friends. Acceptance of "negative" jokes and birthday cards given by a family member or close friend, can be taken as a sign of interpersonal acceptance, whereas the same thing initiated by someone outside the network would be seen as an attack.

Health and assumed competency: Many of the questions in the survey express stereotypes about older persons' competency and abilities. Just fewer than $42 \%$ of all respondents reported that a doctor or nurse assumed their ailments were caused by age. This was the third highest average percentage of all the questions. According to Grant (1996) health professionals are trained to expect that age inevitably will lead to deterioration that occurs over time. So, it appears relatively easy for them to say, "you're old" without looking more deeply into the problem. "Learning to confront ageist assumptions...should be part of the continuing education of all physicians and other health care providers" (Reyes-Ortiz, 1997).

Related to health, just fewer than $20 \%$ of all respondents reported that at least once someone has assumed they couldn't hear because of age and nearly $32 \%$ have been told that they are too old to do something. This is likely to lead to declines in selfefficacy.

Employment: According to Tougas et al. (2004) over a third of the work force in Canada are older workers. Rupp et al. (2006) have explored supervisor's attitudes towards older and younger workers. They found that younger workers were consistently given less severe recommendations regarding problems with their performance. Further, mangers with ageist attitudes gave more severe evaluations of older worker's performance. Finally, Duncan and Loretto (2004) explored other employee's attitudes toward older workers and concluded "There appears to be sufficient grounds to treat ageism as a distinct form of oppression in its own right".

Victimization: According to the Ogrodnik (2007) seniors experience victimization three times less often than non-seniors and seniors-only residents are much less likely to experience break and enter. However, while the victimization rate is lower for seniors, they feel more vulnerable outside their homes (Public Health Agency of Canada, 2007).

Personal rejection: The items combined with and clustered around "treated with less dignity and respect" represent direct attacks on self-esteem. Most certainly, persons in one's close social network would be very careful in asserting these characteristics toward a person outside the context of mutually understood and accepted attempts at humour. No psychologically healthy person responds favourably to being: "Treated with less dignity and respect?, "ignored", "patronized, "assumed to be stupid" or "deaf". According to Leary (2005) "people's self-evaluations on particular dimensions predict their self-esteem primarily to the 
degree that they believe those dimensions have implications for whether other people accept or reject them".

With the exception of humour, used among close associates to reduce tension and confirm friendship, all of the items discussed in this research represent attempts to marginalize and demean older persons.

\section{CONCLUSION}

The findings from this report strongly suggest that programs for building positive intergenerational relationships and better understanding of aging need to be established if our elders are to age successfully during the 21st Century. As a small step we have founded the Intergenerational Centre for Action Learning (ICAL). With Federal funding, we are engaged in a Community Story tellers Project that has younger persons interviewing seniors and then constructing short videos. For more information contact us through our Website ical.ca.

\section{REFERENCES}

Angus, J. and P. Reeve, 2006. Ageism: A threat to "aging well" in the $21 \mathrm{st}$ century. J. Applied Gerontol., 25: 137-152. DOI: 10.1177/0733464805285745

Butler, R.N., 1969. Age-ism: Another form of bigotry. Gerontologist, 9: 243-246.

Duncan, C. and W. Loretto, 2004. Never the right age? Gender and age-based discrimination. Gender, Work Org., 11: 95-115. DOI: 10.1111/j.14680432.2004.00222.x

Ellis, S.R. and T.G. Morrison, 2005. Stereotypes of aging: Messages promoted by age-specific paper birthday cards available in Canada. Int. J. Aging Hum. Dev., 61: 57-73. PMID: 16060333

Grant, L.D., 1996. Effects of ageism on individual and health care providers' responses to healthy aging. Health Soc. Work, 21: 9-15. PMID: 8626163

Lang, F. and L.L. Carstensen, 1994. Close emotional relationships in late life: Further support for proactive aging in the social domain. Psychol. Aging, 9: 315-324. DOI: 10.1037/08827974.9.2.315

Leary, M.R., 2005. Sociometer theory and the pursuit of relational value: Getting to the root of selfesteem. Eur. Rev. Soc. Psychol., 16: 75-111. DOI: 10.1080/10463280540000007
Lipscomb, V.B., 2006. We need a theoretical base: Cynthia rich, women's studies and ageism. Natl. Women's Study Assoc., 18: 3-12. http://muse.jhu.edu/journals/nwsa/summary/v018/1 8.1lipscomb.html

Ogrodnik, L., 2007. Seniors as victims of crime. Canadian Centre for Justice Statistics. http://dsppsd.communication.gc.ca/Collection/Statcan/85F00 33M/85F0033MIE2007014.pdf

Palmore, E., 2001. The ageism survey: First findings. Gerontologist, 41: 1-3. DOI: 10.1111/j.14422018.2007.00336.x

Palmore, E.B., 2004. Research note: Ageism in Canada and the United States. J. Cross-Cult. Gerontol., 19: 41-46. DOI: 10.1023/B:JCCG.0000015098.62691.ab

Palmore, E., 2005. Three decades of research on ageism. Generators, 29: 87-90. http://www.asaging.org/publications/dbase/GEN/G en29_3.Palmore.pdf

Pinker, S., 1999. How the Mind Works. W.W. Norton and Company, New York, ISBN: 9780965838047 , pp: 672 .

Public Health Agency of Canada, 2007. Criminal victimization and fear of crime among Canadian seniors. Public Health Agency of Canada. http://www.phac-aspc.gc.ca/seniorsaines/pubs/factoids/2001/no.11_e.htm

Reyes-Ortiz, C.A., 1997. Physicians must confront ageism. Acad. Med., 72: 831. PMID: 9347700

Rupp, D.E., S.J. Vodanovich and M. Crede, 2006. Age bias in the workplace: The impact of ageism and causal attributions. J. Applied Soc. Psychol., 36: 1337-1364. DOI: 10.1111/j.00219029.2006.00062.x

Stones, M.J. and L. Stones, 1997. Ageism: The quiet epidemic. Can. J. Public Health, 88: 293-294. http://direct.bl.uk/bld/PlaceOrder.do?UIN=035625 010\&ETOC $=$ RN\&from $=$ searchengine

Tougas, F., M. Lagace, R. de la Sablonniere and L. Kocum, 2004. A new approach to the link between identity and relative deprivation in the perspective of ageism and retirement. Int. J. Aging Hum. Dev., 59: $1-23$.

http://cat.inist.fr/?aModele $=$ afficheN\&cpsidt $=1672$ 2118 